\title{
Gener disponerer for multippel sklerose
}

\author{
Norske forskere har påvist genvarianter i immunsystemet som \\ beskytter mot multippel sklerose. De viser at også gener utenfor \\ HLA-komplekset bidrar til utvikling av sykdommen.
}

Multippel sklerose er en betennelsessykdom som rammer sentralnervesystemet på den måten at immunsystemet går til angrep på nervevevet. Årsaken er ikke godt kjent, men både miljøfaktorer og genetiske faktorer er involvert, spesielt gener som uttrykkes på celler i immunforsvaret. Åslaug Rudjord Lorentzen og hennes samarbeidspartnere har påvist nye genvarianter som både beskytter og disponerer for multippel sklerose, og viser at også gener

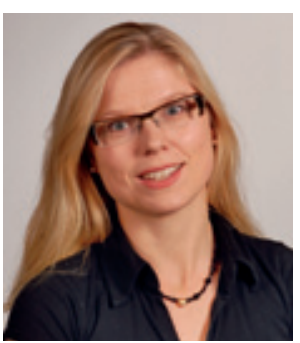

Åslaug Rudjord Lorentzen. Foto Bjørn H. Ohnstad, Rikshospitalet sett på ulike genvarianter hos de syke og hos friske kontrollpersoner, og det vi blant annet viser er at HLA-klasse 1-varianten HLABw4 beskytter mot sykdommen. Assosiasjonen blir også stående etter at vi har kontrollert for den sterkeste genetiske assosiasjonen til multippel sklerose, nemlig HLAklasse 2, som er lokalisert i samme genregion. Vi har også deltatt i store nasjonale og internasjonale samarbeidsprosjekter der vi har gitt viktige bidrag til studier med mange tusen pasienter med multippel sklerose og kontrollpersoner. Slik har vi funnet tre gener utenfor HLA-komplekset som ser ut til å disponere for sykdommen: genene TYK2, CLEC16A og CD226, forteller hun.

Lorentzen forsvarte avhandlingen Immunogenetic studies in multiple sclerosis for ph.d.-graden ved Universitetet i Oslo 6.11. 2009.

\section{Anne Forus}

anneforu@online.no

Tidsskriftet

\section{Ordforklaringer}

HLA: Humant leukocyttantigen.

HLA-Bw4: HLA-variant som er ligand for immunglobulindrepecelleliknende reseptor, som er viktig for aktivering av drepecellene i immunforsvaret. Denne genvarianten var sjeldnere hos pasienter med multippel sklerose.

TYK2: Tyrosinkinase 2

CLEC16A: Medlem av C-type lectindomenefamilie. Man har også funnet at dette genet er assosiert med flere immunmedierte sykdommer, f.eks. type 1-diabetes.

CD226: Klynge av differensieringsmolekyl 226.

\section{«Enkle» tiltak mot fødselsfistel}

\author{
Bare i Etiopia lider 26800 kvinner av ubehandlet fødselsfistel. \\ Ett enkelt tiltak kan hjelpe - nemlig å gi kvinnene samme hjelp som \\ i dag, men på et mye tidligere tidspunkt.
}

Det viser avhandlingen til Mulu Muleta. Hun er etiopisk spesialist i fødselshjelp og kvinnesykdommer og har i nesten 20 år jobbet som fistelkirurg ved Addis Abeba Fistula Hospital. 15.1. 2010 disputerte hun ved Universitetet i Bergen med avhandlingen Obstetric fistula - prevalence, causes, consequences and associated factors.

Én av 400 afrikanske kvinner rammes av obstetrisk fistel. Muleta har funnet at det i gjennomsnitt tar åtte år før kvinnen får medisinsk behandling for skadene. Da er hun for lenge siden utstøtt fra familie og lokalsamfunn på grunn av lukt. Kvinnene selv oppgir også dårlig økonomi, manglende skolegang og opplysning, manglende forståelse i familie og nabolag og lange avstander som årsaker til at de ikke fikk hjelp under og etter fødselen.
- Sykehusene i landet behandler rundt 2000 tilfeller i året, men dette er ikke engang nok til å ta unna de nye tilfellene som hele tiden oppstår. Opplæring av helsepersonell og bedre helsetilbud må til, men det er ett enkelt tiltak som kan hjelpe mye nemlig å få kvinnene til sykehus raskere. Ut fra dataene i studien synes dette å være en realistisk og billig mulighet. Der må ektemenn, familie og naboer mobiliseres. Kvinnen må få hjelp innen de første 24 timene etter at fødselen har stoppet opp. Det vil drastisk redusere skadeomfanget og redde barnets liv. I dag går det i gjennomsnitt tre-fire dager, da er det for sent, sier Muleta.

\section{Eline Feiring}

eline.feiring@legeforeningen.no

Tidsskriftet

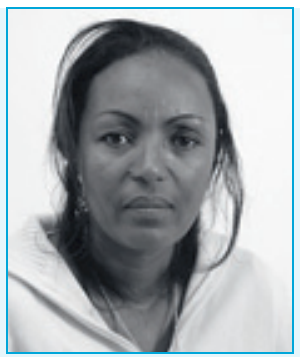

Mulu Muleta. Foto Universitetet i Bergen

\section{Ordforklaringer}

Fødselsfistel: Når barnet sitter fast i fødselskanalen og kvinnen ikke får hjelp, kan $f ø d s e l e n$ stoppe opp i flere døgn. Veggene i fødselskanalen ødelegges ved at sirkulasjonen klemmes av. Resultatet blir kunstig hull mellom skjeden og urinblæren. Også endetarmen og nerver i bekkenet kan rammes, slik at enkelte kvinner får vansker med å gå. Resultatet er at de lekker urin eller avføring gjennom skjeden. I tillegg mister $90 \%$ av disse kvinnene barnet sitt. 